\title{
Amphibian Host and Skin Microbiota Response to a Common Agricultural Antimicrobial and Internal Parasite
}

\author{
Obed Hernández-Gómez ${ }^{1}$ (D) - Vanessa Wuerthner ${ }^{2} \cdot$ Jessica Hua $^{2}$
}

Received: 6 September 2018 / Accepted: 24 February 2019

(C) Springer Science+Business Media, LLC, part of Springer Nature 2019

\begin{abstract}
Holistic approaches that simultaneously characterize responses of both microbial symbionts and their hosts to environmental shifts are imperative to understanding the role of microbiotas on host health. Using the northern leopard frog (Lithobates pipiens) as our model, we investigated the effects of a common trematode (family Echinostomatidae), a common agricultural antimicrobial (Sulfadimethoxine; SDM), and their interaction on amphibian skin microbiota and amphibian health (growth metrics and susceptibility to parasites). In the trematode-exposed individuals, we noted an increase in alpha diversity and a shift in microbial communities. In the SDM-treated individuals, we found a change in the composition of the skin microbiota similar to those induced by the trematode treatment. Groups treated with SDM, echinostomes, or a combination of SDM and echinostomes, had higher relative abundances of OTUs assigned to Flavobacterium and Acinetobacter. Both of these genera have been associated with infectious disease in amphibians and the production of anti-pathogen metabolites. Similar changes in microbial community composition between SDM and trematode exposed individuals may have resulted from stress-related disruption of host immunity. Despite changes in the microbiota, we found no effect of echinostomes and SDM on host health. Given the current diseaseand pollution-related threats facing amphibians, our study highlights the need to continue to evaluate the influence of natural and anthropogenic stressors on host-associated microbial communities.
\end{abstract}

Keywords Lithobates pipiens $\cdot$ Sulfadimethoxine $\cdot$ Echinostomes $\cdot 16 \mathrm{~S}$ rRNA

\section{Introduction}

The contributions of host-associated microbial communities (i.e., microbiotas) to physiological processes of multicellular hosts have been well-documented, and include immune system activation, metabolism, energy uptake, and defense against pathogens [1-4]. However, services provided by microbiotas are associated with the structure and functional

Obed Hernández-Gómez and Vanessa Wuerthner contributed equally to this work.

Electronic supplementary material The online version of this article (https://doi.org/10.1007/s00248-019-01351-5) contains supplementary material, which is available to authorized users.

Obed Hernández-Gómez

obedhg@ berkeley.edu

1 Department of Environmental Science, Policy, and Management, University of California-Berkeley, Berkeley, CA 94720, USA

2 Biological Sciences Department, Binghamton University, Binghamton, NY 13902, USA profiles of the commensal microbial community [5]. Indeed, alterations to host-associated microbial assemblages (i.e., dysbiosis) can result from environmental stress, physiological changes, or parasite invasion resulting in the loss of microbial diversity, increased abundance of pathogenic species, and/or loss of beneficial microbes [6-8]. However, given the tight link between the host condition/environment, symbiont community structure, and host physiological processes, holistic approaches that simultaneously characterize responses of both microbiotas and their hosts to environmental shifts are imperative to understand the role of microbial commensal communities on host health and fitness [9].

Across host systems, the relationship between hostassociated microbiotas and pathogens/parasites has received a lot of attention due to its effects on infectious disease outcomes [10-12]. Microbiotas may interfere with the successful colonization and survival of parasites through exploitative or interference competition [12]. In response, parasites can bypass the protective role of the host microbiome by secreting metabolites that directly affect symbiont abundances, releasing virulent factors that alter host inflammatory responses 
causing indirect changes in the resident community, or by introducing their own symbionts to the host microbiota [13, 14]. In addition, infection-induced changes to the microbiota may also predispose the host to infection with opportunistic pathogens. In Salmo salar, organismal stress caused by parasitism with salmon lice (Lepeophtheirus salmonis) can cause changes in the mucosal microbiota and an increase in the abundance of the pathogenic genera Vibrio, Flavobacterium, Tenacibaculum, and Pseudomonas $[15,16]$. With the impact that microbiota shifts have on the outcome of infectious diseases, it is important to describe indirect sub-lethal effects that parasites may have on microbiotas and ultimately overall host health.

In addition to parasites, as human populations increase, anthropogenic activities (i.e., chemical use) will continue to alter the environments in which host-parasite interactions occur. For example, the influence of pesticides on host-parasite interactions has been widely investigated in a number of systems [17-19]. Given the ubiquitous use of chemicals across the landscape, research extending beyond pesticides is needed. For instance, antimicrobial compounds are commonly used in agricultural livestock to treat and prevent bacterial infections. Through run-off events, these antimicrobial compounds are commonly found across the landscape, including in the soil and aquatic systems [20]. Using wildlife models, some studies demonstrate that clinically relevant doses of antibiotics can alter the protective function of host-associated microbiotas increasing the host's susceptibility to pathogens [21]. However, it is not well understood how environmental concentrations of antimicrobials affect the vulnerability of non-target organisms to parasites or how they alter the microbiota. Given the common co-occurrence of contaminants with parasites in the environment, it is vital to consider how environmentally relevant concentrations of antimicrobials interact with parasites to alter host health and their microbial symbionts.

Amphibians provide a useful study system to holistically explore how parasites and anthropogenic factors influence skin microbiota and host health. The amphibian skin harbors diverse communities of microbes that are highly interactive with the environment, providing the initial defense against external pathogens [22]. For example, chytrid fungus Batrachochytrium dendrobatidis $(B d)$ is a pathogen that attacks keratinized tissue on amphibian skin [23]. Particularly, some studies have shown that a more diverse skin bacterial community can lead to increased survival and decreased $B d$ loads in amphibians $[6,21,24]$. However, while there are multiple studies that examine how skin microbiotas affect host health in response to $B d$, amphibians are also exposed to a diversity of other non-cutaneous parasites. Non-cutaneous parasites (e.g., trematodes) are among the most widespread and abundant parasites in amphibian systems [25]. Internal parasite infections have been associated with negative impacts to the survivorship of individuals through morphological abnormalities and physiological stress [26]. In addition, these parasites often co-occur with lethal fungal and viral pathogens (i.e., $B d$ and Ranaviruses; [27]), and co-infections with trematodes and lethal pathogens can alter disease outcomes [28]. In teleost systems, non-cutaneous parasites have been shown to alter skin microbiome [29]; yet, to date, no study has evaluated how non-cutaneous amphibian parasites influence the amphibian skin microbiota [30]. Because non-cutaneous parasites co-occur with other lethal pathogens, microbiota shifts caused by these parasites could indirectly influence hostmicrobiota-pathogen dynamics relevant to skin pathogens. Given the wide distribution of non-cutaneous parasites, the negative impacts their infections bestow on hosts, and their co-occurrence with relevant cutaneous pathogens (e.g., $B d$ ), it is important to evaluate the effect that non-cutaneous parasite infections bestow on the skin microbiota of amphibians.

In addition to infection with parasites, amphibians are exposed to a diversity of contaminants that have been shown to modify the microbiota [31] and also affect host susceptibility to parasites [32-35], but our understanding of how contaminants interact with parasites to influence the amphibian microbiota remains limited [30]. No study has evaluated whether environmentally relevant concentrations of agricultural antibiotics influence microbial communities on the skin of amphibians [30]. In an avian system, ingestion of low doses of agricultural insecticides shifted the gut microbiota of Japanese quail (Coturnix japonica) living in proximity to agricultural environments [36]. Because life-threatening disease and anthropogenic influence are two of the major contributors to amphibian decline across the globe $[23,37,38]$, understanding the response of amphibians and their microbiotas to parasites and agricultural antibiotics also has broad conservation implications.

Using the northern leopard frog (Lithobates pipiens) as our amphibian model, we investigated the effects of a common agricultural antimicrobial (Sulfadimethoxine; SDM; [39]) and a common trematode parasite (Echinostome sp.; hereafter echinostomes; [27]) on amphibian skin bacterial communities and on host health. Specifically, we asked (1) How does SDM alter the amphibian skin bacterial communities? (2) How do echinostomes alter the amphibian skin bacterial communities? (3) Is there an interaction between SDM and echinostome exposure on skin bacterial communities? and (4) What is the effect of SDM on amphibian health (e.g., growth metrics and susceptibility to echinostomes)?

We predicted that SDM exposure would result in a loss of the amphibian skin bacterial community diversity and a shift in community composition [21]. While we did not expect a direct effect of Echinostome infection on the skin bacterial communities, we anticipated that physiological stress due to parasitic infection may increase diversity of communities on the skin of the amphibians, shift skin microbiota composition, 
and increase the abundance of potential pathogenic taxa [40]. Because we predict that SDM will decrease skin bacterial community diversity but echinostomes will increase diversity, we projected that echinostomes and SDM would interact antagonistically on the amphibian skin bacterial community diversity and composition. Finally, we predicted that exposure to SDM would interfere with echinostome infection within the amphibian host by increasing infection and reducing mass, SVL, and development [41].

\section{Materials and Methods}

\section{Model Contaminant}

SDM (4-amino-N-2,6- dimethoxy-4-pyrimidinyl), is a broadspectrum sulfonamide antimicrobial commonly used in animal agriculture (chickens, cattle, pigs). SDM inhibits the synthesis of folic acid by fungal and bacterial microorganisms; thus, SDM targets organisms that do not produce their own folic acid as opposed to organisms that obtain folic acid via the environment $[42,43]$. In cattle, SDM is egested in urine at $17.49 \%$ of the therapeutic dose and at least $58.4 \%$ has been detected in excrement as a metabolite [44]. Given that manure is routinely applied at the rate of at least 50,000 1 per hectare, many hundreds of grams of SDM can be applied to fields that can run off into aquatic ecosystems [39, 45-49]. Indeed, concentrations up to $36 \mu \mathrm{g} 1^{-1}$ and $703 \mu \mathrm{gl}^{-1}$ of SDM have been detected in ponds and agricultural runoff, respectively, though lower concentrations ranging 0.88 to $2 \mu \mathrm{g} \mathrm{l}^{-1}$ are more common $[39,45,46,49]$.

\section{Model Non-Cutaneous Parasite}

We chose to work with echinostomes, a family of digenetic trematodes. Echinostomes are common amphibian parasites that have been widely detected across the globe $[27,50]$. Echinostomes have complex life cycles, with snails and bivalves serving as the first intermediate hosts, amphibian larvae as the second intermediate host, and birds or mammals serving as definitive hosts [50]. In the first intermediate host, snails are penetrated by miracidia which develop into sporocysts [51]. Sporocysts then form free-living cercariae, which leave the snail, infect amphibian tadpoles by entering through the cloaca, and then encyst in the kidneys of the tadpole $[50,52,53]$. Similar to other macroparasitic infections, the effect of echinostomes on amphibian host pathology (e.g., hemorrhaging, edema) and mortality is dose- and age-dependent, with greater mortality observed with high doses on younger tadpoles $[50,54]$.

\section{Amphibian Collection and Husbandry}

On 29 March 2016, we collected ten partial northern leopard frog (L. pipiens) egg masses from a pond located near the Purdue Wildlife Area (PWA) in West Lafayette, IN $\left(40.4457^{\circ},-87.0505^{\circ}\right)$. All animals were collected as recently laid egg masses to avoid using animals with prior infections to parasites and to avoid exposure to contaminants. The egg masses were immediately transported to the Ecological Research Facility (ERF) at Binghamton University. Each egg mass was split into two and divided into two outdoor 225-1 pools filled with $\sim 2001$ of well water. Once leopard frogs hatched and developed into the tadpole stage, we fed them rabbit chow ad libitum until the start of the experiment.

\section{Experimental Design}

To allow natural colonization of microbes on the amphibian skin, we first reared tadpoles in semi-natural mesocosms for 10 days ([55]; mesoscosm set up protocol can be found in Supplementary Material). We randomly assigned five mesocosms to a $0 \mu \mathrm{g} \mathrm{l}^{-1}$ of SDM treatment and five mesocosms to a $1 \mu \mathrm{g} \mathrm{l}^{-1}$ of SDM treatment. We chose $1 \mu \mathrm{g}^{-1}$ of SDM because it mimics an environmentally relevant concentration of SDM (stock SDM protocol and concentration validation can be found in Supplementary Material; $[39,45,46,49])$. Following the addition of either SDM or well water, we size-selected and added 25 individual leopard frog tadpoles to each mesocosm. Finally, we replicated the same SDM dosing procedure twice more on the 5th and 9th of July.

On July 11 (day 0 ), we randomly collected 40 tadpoles from the $0 \mu \mathrm{g}^{-1}$ and 40 tadpoles from the $1 \mu \mathrm{g} \mathrm{l^{-1 }}$ SDM mesocosms and transferred them into the laboratory to initiate the parasite exposure experiments $(N=80 ;$ Fig. 1$)$. Once in the lab, all tadpoles (average mass $=1.1 \pm 0.1 \mathrm{~g}$ ) were individually held in 2-1 tubs filled with 11 of filtered, UV-irradiated aged well water for 2 days. We then exposed 20 tadpoles from the $0 \mu \mathrm{g} \mathrm{l}^{-1}$ of SDM mesocosm group and 20 tadpoles from the $1 \mu \mathrm{g}^{-1}$ of SDM mesocosm group to 50 echinostome cercariae (parasite collection protocol can be found in Supplementary Material). For the 20 remaining tadpoles from the $0 \mu \mathrm{g} \mathrm{l}^{-1}$ of SDM mesocosms and 20 tadpoles from the $1 \mu \mathrm{g} 1^{-1}$ of SDM mesocosms not assigned echinostomes, we repeated this procedure by adding the same volume of water from an uninfected snail. Because this study focused only on how host-exposure to SDM effects host health and microbiome, all tadpoles were temporarily $(48 \mathrm{~h})$ held in antimicrobial-free UV-filtered well water during the parasite exposure procedure. This was done to avoid any potential effects of SDM on the ability for echinostome cercariae to infect tadpoles [34]. We chose $48 \mathrm{~h}$ because past studies 


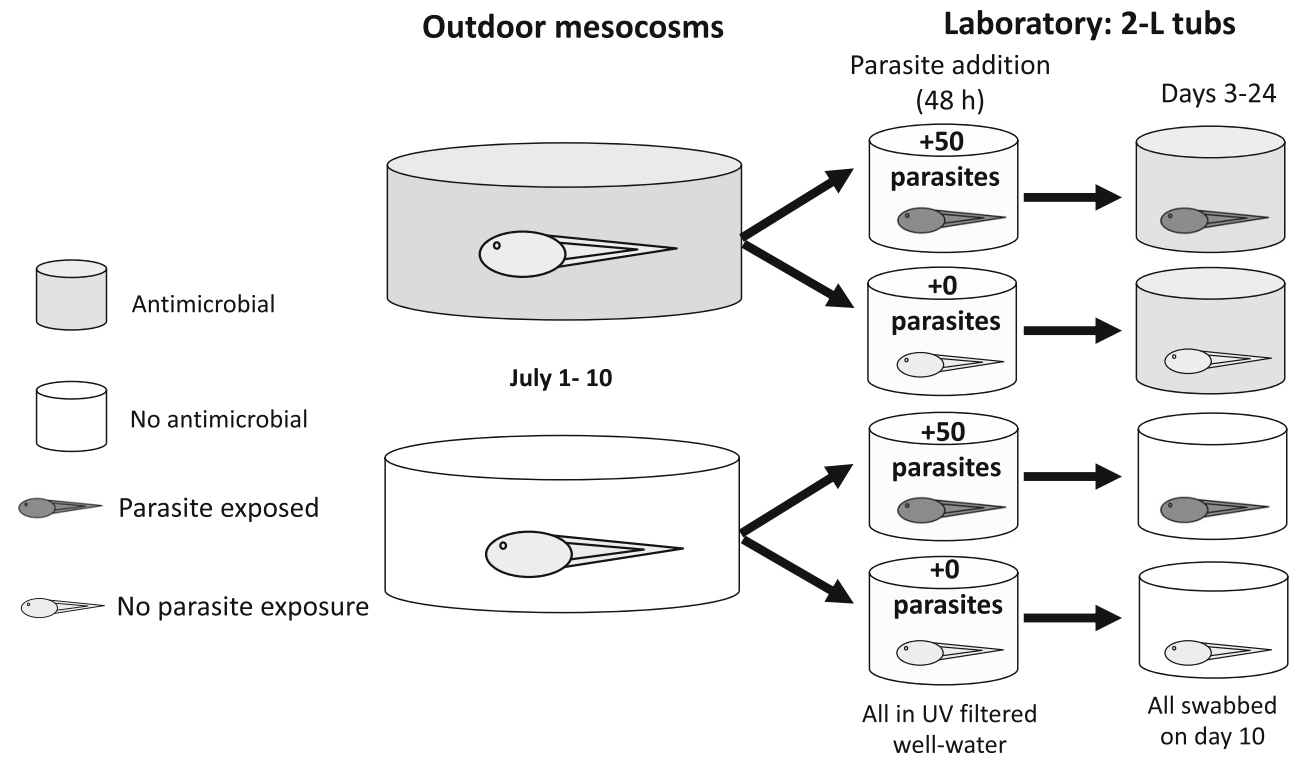

Fig. 1 Movement of tadpoles throughout $2 \times 2$ factorial experiment using antimicrobial (SDM) and echinostome parasite exposure

indicate this is sufficient time for cercariae to successfully encyst in the tadpole kidney $[28,33,34]$.

After $48 \mathrm{~h}$ (day 2), individual tadpoles from the original $0 \mu \mathrm{g}^{-1}$ of SDM mesocosms were placed into 2-1 of units filled with 11 of filtered, UV-irradiated aged well water while tadpoles from the original $1 \mu \mathrm{g} \mathrm{l}^{-1}$ of SDM mesocosms were placed into 2-1 of units containing 11 of $1 \mu \mathrm{g} \mathrm{l}^{-1}$ of SDM (Fig. 1). A recent study demonstrated that pathogens can significantly alter the microbial community structure on amphibians within 7 days [56]. Given this time frame, on July 21 (day 10), we randomly chose ten individuals from each treatment and swabbed their skin microbiota (total number of tadpoles swabbed was 40). Prior to swabbing, each individual was handled with new nitrile gloves and was rinsed with $100 \mathrm{ml}$ of sterile water to ensure the sample included predominantly amphibian skin-associated microbes [57]. Immediately after rinsing, each tadpole was uniformly sampled using a cotton-tipped swab over the entire surface of the body for $30 \mathrm{~s}$ [58]. Individuals were placed back into the experimental units immediately after swabbing. Each swab was placed in a sterile $1.5-\mathrm{ml}$ microcentrifuge tube and stored at $-80{ }^{\circ} \mathrm{C}$ until DNA extraction.

Past work demonstrates that some tadpoles infected with echinostomes can clear the parasite within 14 days of exposure [59]. Therefore, to allow tadpoles time to mount these responses, we held tadpoles for an additional 14 days after swabbing for their microbiome. During this time, tadpoles were monitored daily for signs of disease (e.g., edema and hemorrhaging) and mortality. Tadpoles were fed a 1:1 ground TetraMin mixed with water diet ad libitum every 2 days. Water changes were conducted every 5 days at which point we renewed the $0 \mu \mathrm{g} \mathrm{I}^{-1}$ or $1 \mu \mathrm{g} \mathrm{I}^{-1} \mathrm{SDM}$ treatments. On day
24, all tadpoles were euthanized using MS-222 and preserved in $70 \%$ ethanol. We weighed, staged, and dissected all preserved tadpoles and viewed the tissues under a dissecting scope to quantify the number of encysted echinostomes [60]. We examined $10 \%$ of all control individuals to confirm the absence of echinostome infection; all individuals were negative for the trematode [28]. To account for any potential effect of the time lag between swabbing tadpole microbiota (day 10) and measuring host health metrics (day 24), we compared day 24 parasite loads to a subset of tadpoles that were taken down on day 10 and demonstrated that parasite loads did not significantly differ between these two time points $\left(F_{1,58}=1.4 ; p=\right.$ 0.23 ; Supplementary Material).

\section{Microbiota Laboratory Methods}

We isolated DNA from skin swabs using the PowerSoil DNA Isolation Kit (MoBio Laboratories Inc., Carlsbad, CA) following the protocol described in Hernández-Gómez et al. [61]. We then implemented two sequential PCRs to prepare our amplicon sequencing library using the methodology described in Hernández-Gómez et al. [62]. In brief, we amplified the bacterial 16S rRNA V2 region using primer pair $27 \mathrm{~F} / 338 \mathrm{R}$ [63] with the attachment of connector sequences, multiplex barcodes, and Illumina adaptors [62]. We quantified the barcoded amplicons using a Qubit Fluorometer (Invitrogen Corp, Carlsbad, CA), pooled samples in equimolar amounts, and cleaned sample pools using the UltraClean PCR Clean-up kit (MoBio Laboratories Inc., Carlsbad, CA). We overnighted the barcoded sample pool on dry ice to the Cornell University Biotechnology Resource Center. The sample pool was sequenced on a MiSeq machine (Illumina, Inc. San Diego, 
CA) using the reagent kit V2 to produce 250-bp paired-end reads.

\section{Amplicon Sequence Analysis}

We processed raw sequencing reads using Trimmomatic [64] to remove adapter sequences, bases below threshold quality of phred-20 from both ends of reads, and any resulting reads under $30 \mathrm{bp}$. We paired reads that passed initial quality control using PANDAseq [65] and only retained reads that paired successfully. Raw sequencing data was uploaded to the NCBI Sequence Read Archive under the project accession number PRJNA429454.

We implemented the Quantitative Insights Into Microbial Ecology version 1.9.0 (QIIME) pipeline [66] to filter erroneous reads, cluster reads into operational taxonomic units (OTUs), and generate abundance-based OTU tables. We clustered reads at the standard $97 \%$ similarity using the openreference protocol [67] and the Greengenes 13_5 reference database [68] as in Hernández-Gómez et al. [61]. OTU taxonomy data was retrieved from Greengenes assignments performed in QIIME with an additional search of sequences in the Ribosomal Database Project (RDP) to resolve unassigned sequences [69]. To avoid including any OTUs generated by sequencer error, such as base miscalls or chimeras, we performed additional quality filtration on the OTU table by removing OTUs that were represented by fewer than $0.005 \%$ of the total read count [70]. To standardize sequencing depth across all samples, we rarefied the OTU table to 17,490 sequences per sample.

\section{Statistical Analysis}

We transferred the rarefied OTU table and Newick phylogenetic tree to $\mathrm{R}$ (version 3.2.0). To evaluate alpha diversity, we calculated community richness (observed OTUs), evenness (Shannon diversity), and phylogenetic diversity (Faith's phylogenetic diversity) using the packages vegan [71] and picante [72]. In addition, we implemented the packages GuniFrac [73] and vegan to calculate pairwise unweighted/weighted UniFrac distances and Bray-Curtis dissimilarities between samples. We chose to calculate these three measures of beta diversity as they account for phylogenetic presence/absence-based differences (unweighted UniFrac), phylogenetic abundance-based differences (weighted UniFrac), and non-phylogenetic abundance-based differences (Bray-Curtis) among samples.

We evaluated the effect of SDM and echinostome exposure on richness, phylogenetic-based, and evenness measures of alpha diversity (OTU richness, Faith's phylogenetic diversity, and Shannon index) using generalized linear models. We tested differences in alpha diversity based on SDM exposure, echinostome exposure, and the combined effect of SDM and echinostome exposure. To test differences in OTU richness, we applied a negative binomial linear model using the R package MASS [74]. We implemented a linear model using a normal error distribution to evaluate differences in Shannon diversity and Faith's phylogenetic diversity.

We assessed differences in community composition among samples based on SDM and echinostome exposure using multivariate tests. To characterize the strength and significance of differentiation among control (no SDM/no echinostome exposure) and exposure (SDM, echinostome, and SDM + echinostome exposure) groups, we implemented a two-way PERMANOVA test with interaction term using all three beta diversity metrics. We generated NMDS plots using weighted UniFrac, unweighted UniFrac, and Bray-Curtis dissimilarities to visualize clustering of samples by treatment group. We performed an indicator species analysis using the $\mathrm{R}$ package indicspecies [75] to evaluate which OTUs were responsible for differences among groups and to quantify the strength of associations between OTU relative abundances and treatment groups.

Host health analyses were conducted using SPSS 22.0 (SPSS Inc., Chicago, IL). We used Pearson's correlation to determine whether there was an association between Gosner stage, mass, snout-vent length (SVL), and total length (TL) and found that all four response variables were highly correlated $(p<0.001)$ and all distributional assumptions were met. Gosner stage refers to the tadpole's development stage and is quantified using a generalized morphological staging table [76]. Therefore, we conducted a factor reduction analysis using Principal Axis Factoring with an orthogonal Varimax rotation (SPSS; factor reduction) to facilitate interpretations between these variables. We reduced our four variables into a single predictor (PC-1). We ran a univariate analysis of variance (ANOVA) to determine if echinostomes, SDM, and their interaction had an effect on PC-1. Additionally, we used an independent $t$ test to examine the effects of SDM on echinostome infection.

\section{Results}

From 40 northern leopard frog bacterial community samples, 16S rRNA V2 amplicon sequencing resulted in 1,718,076 reads. After filtering out reads by base pair length, we processed the remaining reads through QIIME using the open reference clustering method to return 881 OTUs for all skin samples after OTU abundance filtration and rarefaction.

SDM exposure alone was not associated with differences in microbial community alpha diversity between control and SDM-exposed individuals (richness, $F_{1,36}=0.39, p=0.538$; Faith's phylogenetic diversity, $F_{1,36}=1.00, p=0.323$; Shannon diversity, $F_{1,36}=0.25, p=0.624$; Fig. 2). However, tadpoles exposed to echinostomes possessed more even 

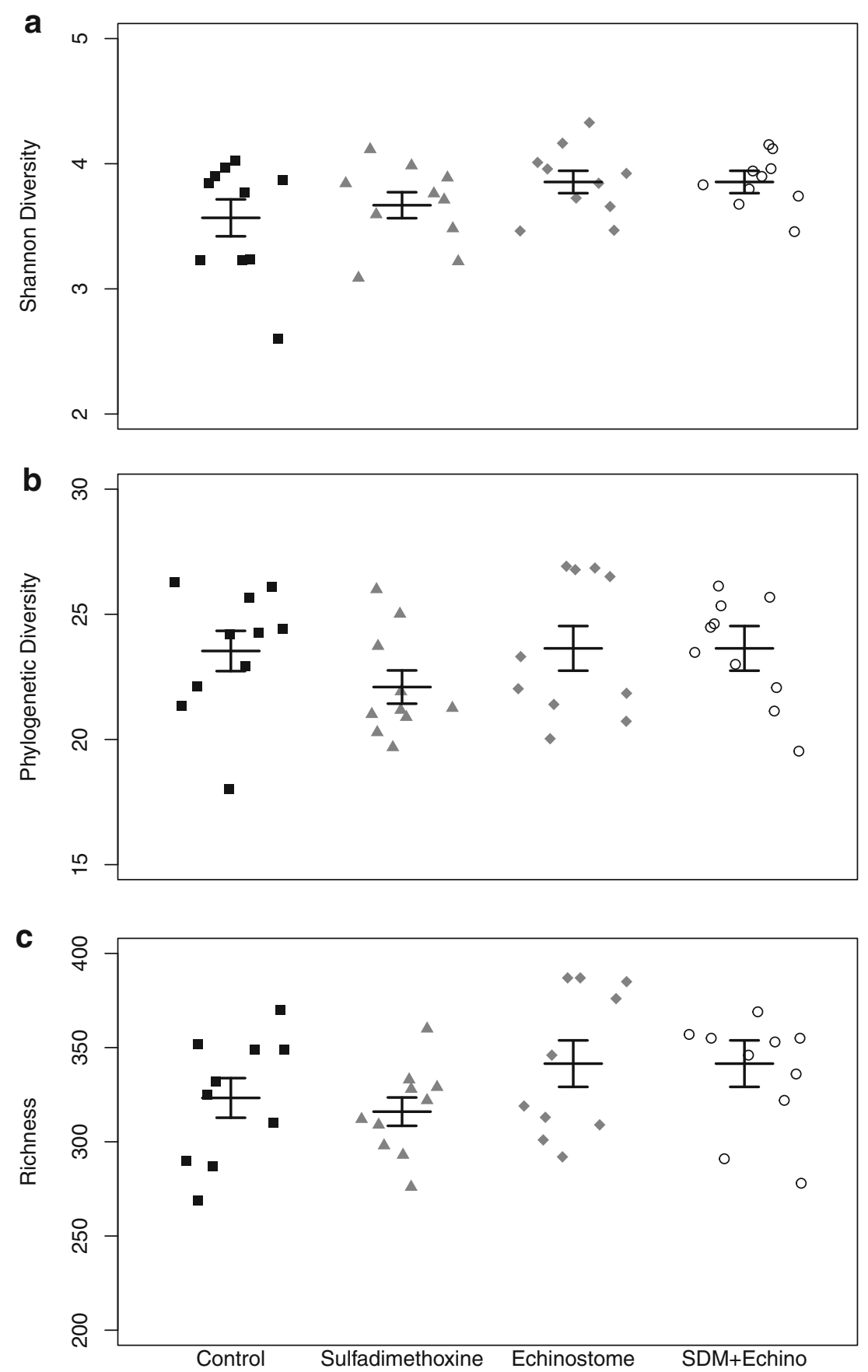

Fig. 2 Dot plot of Shannon diversity (A), Phylogenetic diversity (B), and richness $(\mathbf{C})$ values from northern leopard frog skin microbial communities. Control, Sulfadimethoxine, echinostome, and combined echinostome and Sulfadimethoxine (SDM + Echino)-exposed groups are represented. Mean values for each group are represented through longer horizontal lines, and error values through the shorter lines communities than the control (richness, $F_{1,36}=3.59, p=$ 0.066; Faith's phylogenetic diversity, $F_{1,36}=1.04, p=0.315$; Shannon diversity, $F_{1,36}=4.40, p=0.043$; Fig. 2 ). We did not detect a significant interaction between SDM and echinostome exposure (richness, $F_{1,36}=0.01, p=0.922$; Faith's phylogenetic diversity, $F_{1,36}=0.78, p=0.384$; Shannon diversity, $F_{1,36}=1.52, p=0.648$; Fig. 2 ).
We detected differences in community composition between control and SDM groups for unweighted UniFrac and BrayCurtis beta diversity metrics (Table 1). Using all three metrics (i.e., unweighted UniFrac, weighted UniFrac, and Bray-Curtis), we also found a significant effect of echinostome exposure on the composition of the skin microbial communities (Table 1). We only found a near-significant interaction between SDM and 
Table 1 Two-way PERMANOVA test among microbial communities from Sulfadimethoxine- (SDM) and echinostome-exposed northern leopard frogs. $F$-statistic and $p$ value are presented for each comparison performed on weighted UniFrac, unweighted UniFrac, and Bray-Curtis distances. Significant results at $p$ value $<0.05$ are italicized

\begin{tabular}{llll}
\hline Groups & Weighted UniFrac & Unweighted UniFrac & Bray-Curtis \\
\hline SDM & $F_{1,36}=1.52 ;$ & $F_{1,36}=2.05 ;$ & $F_{1,36}=2.03 ;$ \\
& $p=0.150$ & $p=0.010$ & $p=0.012$ \\
Echinostome & $F_{1,36}=3.00 ;$ & $F_{1,36}=3.15 ;$ & $F_{1,36}=2.69 ;$ \\
& $p=0.010$ & $p=0.001$ & $p=0.001$ \\
Interaction & $F_{1,36}=1.01 ;$ & $F_{1,36}=1.34 ;$ & $F_{1,36}=1.53 ;$ \\
& $p=0.367$ & $p=0.119$ & $p=0.066$ \\
\hline
\end{tabular}

echinostome exposure on beta diversity using Bray-Curtis dissimilarities only (Table 1). We visualized clustering of samples between control and treatment groups for NMDS plots generated using unweighted UniFrac and Bray-Curtis metrics (Fig. 3). When comparing the effect of SDM on average beta diversity in tadpoles exposed to echinostomes vs. tadpoles not exposed to echinostomes, the effect of SDM on average beta diversity was larger in the absence of echinostomes compared to in the presence of echinostomes (Fig. 4). Therefore, while both SDM and echinostomes individually initiated a change on the composition of the skin microbial communities in the tadpole, the presence of the parasite may have dampened the effect of the antimicrobial on the skin microbiota.

The indicator species analysis associated 56 OTUs with SDM-exposed individuals (Table 2). The most abundant OTUs (at an average relative abundance $>0.001 \%$ ) included those assigned to the genera Emticicia, Flavobacterium, Acinetobacter, Prosthecobacter, Limnobacter, Pedobacter, Leadbeterella, Flectobacillus, and Methyloptenera; the families Flavobacteriaceae, Aeromonadaceae, Enterobacteriaceae, Sinobaceraceae, Verrucomicrobiaceae, Comamonadaceae, and Sphingomonadaceae; and the class Betaproteobacteria. Fifty-nine OTUs were associated with echinostome-exposed individuals (Table 2). Similar to SDM-exposed individuals,
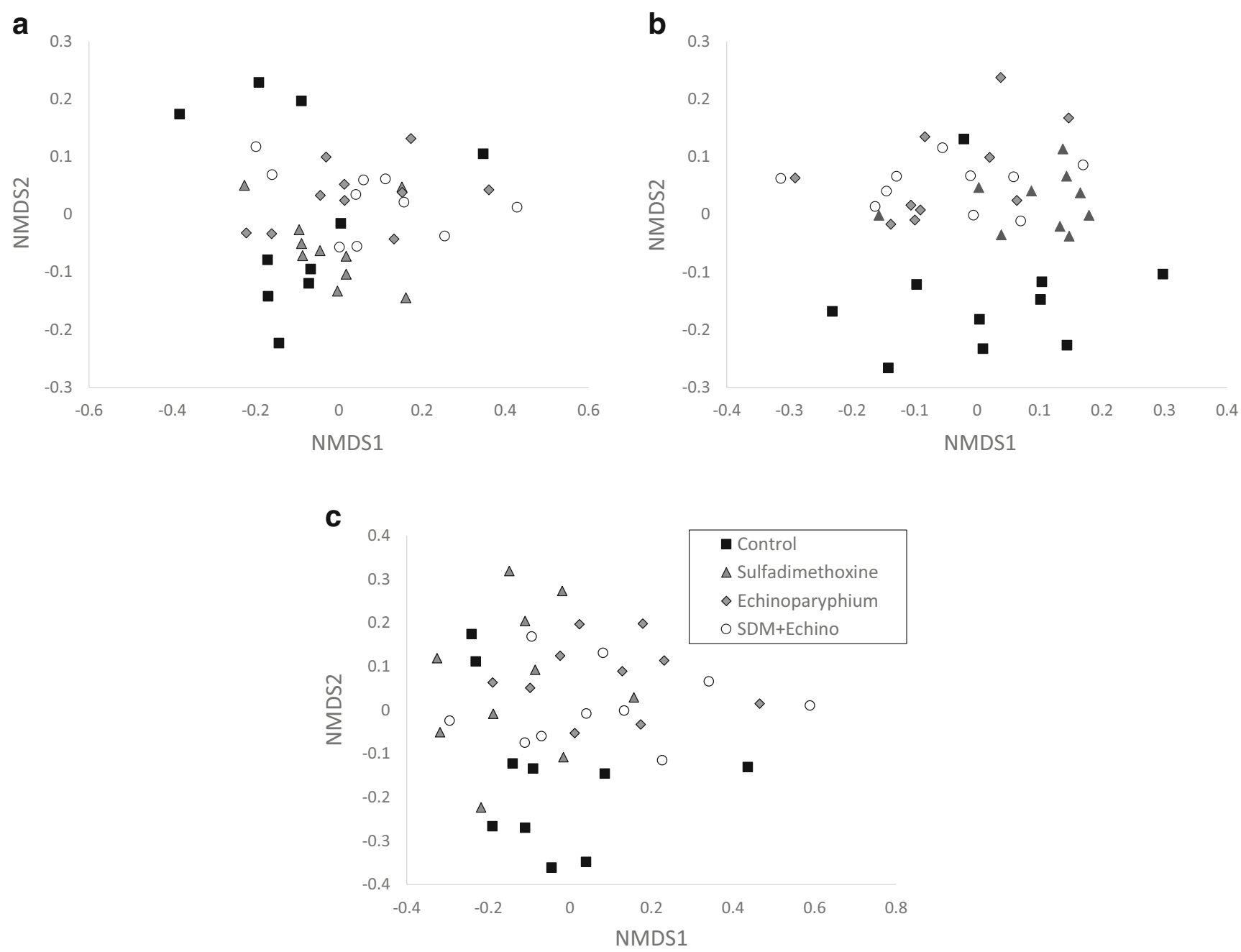

Fig. 3 NMDS ordination plot of northern leopard frog skin microbiota samples using weighted UniFrac $(\mathbf{A}$; stress $=0.15)$, unweighted UniFrac $(\mathbf{B}$; stress $=0.19)$, and Bray-Curtis $(\mathbf{C}$; stress $=0.23)$ distances 

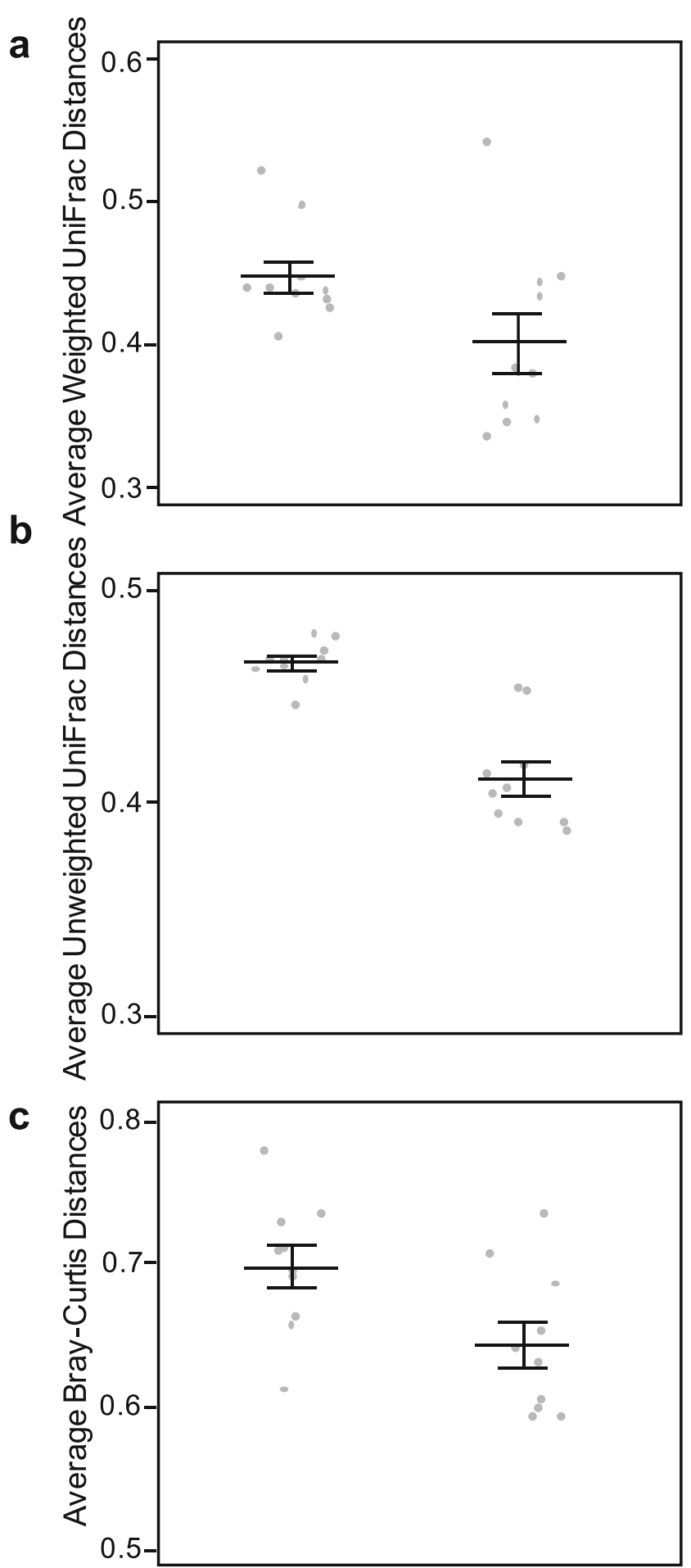

No Echinostome Echinostome

Fig. 4 Average beta diversity distances between Sulfadimethoxine and non-Sulfadimethoxine-exposed individuals in no echinostome and echinostome-exposed groups. Weighted UniFrac (A), unweighted UniFrac (B), and Bray-Curtis (C) distances are presented

echinostome-exposed individuals were associated with OTUs assigned to the genera Emticicia, Flavobacterium, Acinetobacter, Prosthecobacter, and Methyloptenera; the families Flavobacteriaceae, Comamonadaceae,
Enterobacteriaceae, Sinobaceraceae, Verrucomicrobiaceae; and the class Betaproteobacteria. Other abundant OTUs associated with echinostome-exposed individuals include those assigned to the genera Rheinheimera, Luteolibacter, and Propionivibrio; the families Cytophagaceae and Fusobacteriaceae; and the order Clostridiales. The indicator species analysis associated 66 OTUs with echinostome + SDM-exposed individuals (Table 2). Tadpoles exposed to the SDM + echinostome treatment shared OTU associations with tadpoles exposed to SDM and tadpoles exposed to echinostomes. Shared OTUs include those assigned to the genera Emticicia, Flavobacterium, Pedobacter, Limnobacter, Propiniovibrio, Methyloptenera, Acinetobacter, Luteolibacter, and Prosthecobacter; the families Cytophagaceae, Comamonadaceae, Enterobacteriaceae, Sinobaceraceae, and Verrucomicrobiaceae; the order Clostridiales; and the class Betaproteobacteria. Abundant OTUs exclusively assigned to the SDM + echinostomeexposed individuals include those assigned to the genus Leadbeterella, the family Chitinophagaceae, and the order Sphingobacteriales.

We found no significant effect of echinostome $\left(F_{1,76}=\right.$ $3.219, p=0.077), \operatorname{SDM}\left(F_{1,76}=0.421, p=0.516\right)$, or their interaction $\left(F_{1,76}=0.235, p=0.628\right)$ on tadpole size (PC-1; average $\mathrm{PC}-1 \pm \mathrm{SE}$, control $=0.33 \pm 0.24, \mathrm{SDM}=0.07 \pm$ 0.21, Echino $=-0.18 \pm 0.20, \mathrm{SDM}+$ Echino $=-0.24 \pm$ 0.23 ). Additionally, there was no evidence that SDM influenced echinostome infection (average encysted echinostome $\pm \mathrm{SE}, \mathrm{SDM}=6.65 \pm 1.06$, no $\mathrm{SDM}=6.95 \pm 1.13, F_{1,38}=$ $0.002, p=0.847)$.

\section{Discussion}

We demonstrated that SDM and echinostomes altered amphibian skin microbial communities. Specifically, while exposure to SDM did not alter alpha diversity of skin bacterial communities (richness or diversity), SDM did modify beta diversity (microbial community composition). In contrast, exposure to echinostomes resulted in a slight increase in alpha diversity (microbial community richness) and a change in beta diversity (community composition). We did not find a significant interaction between SDM and echinostome exposure on alpha diversity or beta diversity. For all treatment groups (SDM-only, echinostome only, and echinostome + SDM), we found similar changes in the relative abundance of specific bacteria. Notably, all treatment groups had an increased relative abundance in the genera Emticicia, Flavobacterium, Acinetobacter, and Prosthecobacter; the families Enterobacteriaceae, Sinobaceraceae, and Verrucomicrobiaceae; and the class Betaproteobacteria. Finally, despite the effect of SDM and echinostomes on the amphibian microbiome, these 
Table 2 Indicator operational taxonomic units (OTUs) among northern leopard frog treatment groups. The OTU list is broken down by OTU associations to sample group(s). The average relative abundance of each OTU is displayed for each treatment group ( $C$ control, $A$ sulfadimethoxine,
$P$ echinostome, and $P / A$ echinostome and sulfadimethoxine). The relative abundance cells are shaded based on their value with 0 in white and the max value of 0.05 in black. For each OTU, the association statistic and corresponding $\mathrm{p}$ value are presented as well as its taxonomy

\begin{tabular}{|c|c|c|c|c|c|c|c|}
\hline OTUs & C & $\mathbf{A}$ & $\mathbf{P}$ & $\mathbf{P} / \mathbf{A}$ & Ass. & p-val & Genus \\
\hline \multicolumn{8}{|c|}{ Control Only } \\
\hline N.R.1404 & 5.1E-05 & 0 & 1.1E-05 & 0 & 0.64 & 0.020 & Acidimicrobiales (O) \\
\hline 2692410 & 8.0E-05 & 0 & 1.7E-05 & 5.7E-06 & 0.74 & 0.005 & Microbacterium \\
\hline 528336 & 2.7E-04 & 5.7E-06 & 2.3E-05 & $1.1 \mathrm{E}-05$ & 0.72 & 0.005 & Chitinophagaceae (F) \\
\hline N.C.R.161793 & $1.3 \mathrm{E}-03$ & 1.0E-04 & 2.3E-05 & 8.0E-05 & 0.78 & 0.020 & Chitinophagaceae (F) \\
\hline 805098 & 5.0E-04 & 0 & 0 & 5.7E-06 & 0.63 & 0.030 & Saprospiraceae (F) \\
\hline N.R.221 & $9.1 \mathrm{E}-05$ & 5.7E-06 & 0 & 5.7E-06 & 0.60 & 0.015 & Gemmatimonas \\
\hline 4407152 & $1.2 \mathrm{E}-04$ & 0 & 0 & 0 & 0.71 & 0.005 & Planctomyces \\
\hline 4387422 & 5.0E-04 & $3.4 \mathrm{E}-05$ & 5.7E-06 & $2.3 \mathrm{E}-05$ & 0.73 & 0.020 & Devosia \\
\hline N.R.1336 & $6.9 \mathrm{E}-05$ & 0 & $1.1 \mathrm{E}-05$ & 0 & 0.65 & 0.020 & Rhodoplanes \\
\hline 106732 & 1.7E-04 & 0 & 0 & 5.7E-06 & 0.82 & 0.005 & Methylocystaceae (F) \\
\hline 530619 & $9.1 \mathrm{E}-05$ & $1.1 \mathrm{E}-05$ & 0 & 5.7E-06 & 0.71 & 0.010 & Hyphomonadaceae (F) \\
\hline 589946 & $6.9 \mathrm{E}-05$ & 0 & 5.7E-06 & 0 & 0.68 & 0.010 & Hyphomonadaceae (F) \\
\hline N.R.714 & $1.3 \mathrm{E}-04$ & 5.7E-06 & 0 & 5.7E-06 & 0.61 & 0.030 & Rhodococcus \\
\hline N.R.935 & 2.9E-04 & 4.0E-05 & $3.4 \mathrm{E}-05$ & 1.7E-05 & 0.78 & 0.005 & Acetobacteraceae (F) \\
\hline N.C.R.273470 & $2.5 \mathrm{E}-04$ & 5.7E-06 & 0 & 0 & 0.77 & 0.005 & Alphaproteobacteria (C) \\
\hline 4426763 & 1.6E-02 & 2.3E-03 & 1.1E-04 & $5.4 \mathrm{E}-04$ & 0.82 & 0.010 & Comamonadaceae (F) \\
\hline 4430763 & $1.9 \mathrm{E}-04$ & 5.7E-06 & 1.7E-05 & $2.9 \mathrm{E}-05$ & 0.80 & 0.005 & Comamonadaceae (F) \\
\hline N.R.571 & $6.4 \mathrm{E}-04$ & $1.1 \mathrm{E}-05$ & 0 & 0 & 0.77 & 0.005 & Comamonadaceae (F) \\
\hline 539852 & $2.8 \mathrm{E}-03$ & 7.4E-05 & $1.2 \mathrm{E}-04$ & 1.7E-04 & 0.94 & 0.005 & Neisseriaceae (F) \\
\hline 932848 & $2.2 \mathrm{E}-04$ & $1.1 \mathrm{E}-05$ & 5.7E-06 & 0 & 0.75 & 0.005 & Nitrosomonadaceae (F) \\
\hline N.R.1009 & $1.8 \mathrm{E}-03$ & $2.2 \mathrm{E}-04$ & $1.4 \mathrm{E}-04$ & $1.6 \mathrm{E}-04$ & 0.84 & 0.005 & Methyloversatilis \\
\hline N.R.695 & 4.5E-04 & 9.7E-05 & 5.7E-06 & $6.3 \mathrm{E}-05$ & 0.71 & 0.020 & Myxococcales (0) \\
\hline 243185 & $2.2 \mathrm{E}-03$ & 8.6E-05 & 0 & $3.5 \mathrm{E}-04$ & 0.82 & 0.005 & Aeromonadaceae (F) \\
\hline N.C.R.483200 & 2.7E-04 & $1.1 \mathrm{E}-05$ & 4.0E-05 & 1.1E-05 & 0.70 & 0.025 & Nevskia \\
\hline 548799 & 7.1E-04 & 5.7E-06 & 4.0E-05 & 1.7E-05 & 0.80 & 0.015 & Xanthomonadaceae (F) \\
\hline 4463771 & $3.9 \mathrm{E}-04$ & 0 & 2.3E-05 & 5.7E-06 & 0.68 & 0.035 & Xanthomonadaceae (F) \\
\hline 1054065 & $1.8 \mathrm{E}-03$ & 5.7E-06 & 2.1E-04 & 1.7E-05 & 0.79 & 0.015 & Cerasicoccaceae (F) \\
\hline N.R.1184 & $1.1 \mathrm{E}-03$ & 0 & 5.7E-06 & $2.9 \mathrm{E}-05$ & 0.93 & 0.005 & Myxococcales (0) \\
\hline N.R.1335 & $7.4 \mathrm{E}-05$ & $1.1 \mathrm{E}-05$ & $2.9 \mathrm{E}-05$ & 5.7E-06 & 0.70 & 0.025 & Limnohabitans \\
\hline \multicolumn{8}{|c|}{ SDM Only } \\
\hline N.R.444 & 0 & 7.9E-04 & 0 & $5.1 \mathrm{E}-05$ & 0.61 & 0.030 & Flectobacillus \\
\hline 4456104 & 0 & 1.1E-03 & $3.4 \mathrm{E}-05$ & $2.3 \mathrm{E}-05$ & 0.75 & 0.035 & Comamonadaceae (F) \\
\hline
\end{tabular}


Table 2 (Continued)

\begin{tabular}{|c|c|c|c|c|c|c|c|}
\hline OTUs & C & $\mathbf{A}$ & $\mathbf{P}$ & $\mathbf{P} / \mathbf{A}$ & Ass. & p-val & Genus \\
\hline \multicolumn{8}{|c|}{ Echinostome Only } \\
\hline N.R.67 & 0 & 0 & 4.0E-03 & 8.0E-05 & 0.77 & 0.005 & Flavobacterium \\
\hline N.R.726 & 0 & 0 & 1.7E-05 & 0 & 0.55 & 0.030 & Rhodobacter \\
\hline N.R.1002 & 4.0E-05 & $2.3 \mathrm{E}-05$ & $4.6 \mathrm{E}-04$ & 2.9E-05 & 0.71 & 0.020 & Prosthecobacter \\
\hline N.C.R.542651 & 0 & 0 & $1.3 \mathrm{E}-03$ & $2.8 \mathrm{E}-04$ & 0.64 & 0.020 & Cytophagales (O) \\
\hline \multicolumn{8}{|c|}{ SDM/Echinostome only } \\
\hline N.C.R.415568 & 4.0E-05 & $6.9 \mathrm{E}-05$ & $6.3 \mathrm{E}-05$ & $1.4 \mathrm{E}-03$ & 0.84 & 0.005 & Chitinophagaceae (F) \\
\hline 589593 & 0 & 5.7E-06 & 2.9E-05 & 8.4E-04 & 0.76 & 0.010 & Sphingobacteriales (O) \\
\hline N.R.260 & 0 & 0 & 5.7E-06 & 9.7E-05 & 0.53 & 0.035 & Ruminococcus \\
\hline N.R.224 & 5.7E-06 & $1.1 \mathrm{E}-05$ & 4.0E-05 & 4.4E-04 & 0.67 & 0.015 & Clostridiales (O) \\
\hline N.R.43 & $1.1 \mathrm{E}-05$ & 0 & 0 & 8.6E-05 & 0.59 & 0.045 & Bacillaceae (F) \\
\hline \multicolumn{8}{|c|}{ Control + SDM } \\
\hline 336364 & $6.3 \mathrm{E}-05$ & $1.5 \mathrm{E}-04$ & $1.1 \mathrm{E}-05$ & $1.1 \mathrm{E}-05$ & 0.74 & 0.015 & Rhizobiaceae (F) \\
\hline 1115854 & $6.9 \mathrm{E}-05$ & $1.9 \mathrm{E}-04$ & $1.1 \mathrm{E}-05$ & 0 & 0.73 & 0.010 & Sphingomonadaceae (F) \\
\hline 524203 & $2.2 \mathrm{E}-03$ & $4.6 \mathrm{E}-04$ & 1.7E-04 & $9.1 \mathrm{E}-05$ & 0.93 & 0.005 & Comamonadaceae (F) \\
\hline N.R.408 & $1.2 \mathrm{E}-03$ & 8.3E-03 & $1.3 \mathrm{E}-04$ & $6.5 \mathrm{E}-04$ & 0.94 & 0.005 & Verrucomicrobia (P) \\
\hline N.R.587 & 3.3E-04 & $1.4 \mathrm{E}-03$ & $2.9 \mathrm{E}-05$ & $1.8 \mathrm{E}-04$ & 0.82 & 0.015 & Unassigned Bacteria \\
\hline \multicolumn{8}{|c|}{ Control + Echinostome } \\
\hline N.R.437 & $1.2 \mathrm{E}-02$ & 1.1E-04 & $1.5 \mathrm{E}-02$ & $1.5 \mathrm{E}-03$ & 0.90 & 0.005 & Fusobacteriaceae (F) \\
\hline 156616 & $3.5 \mathrm{E}-04$ & 0 & $2.0 \mathrm{E}-04$ & $5.7 \mathrm{E}-06$ & 0.83 & 0.005 & Rhodobacter \\
\hline N.R.584 & 4.5E-04 & 1.7E-05 & 1.6E-04 & $7.4 \mathrm{E}-05$ & 0.86 & 0.005 & Rhodobacter \\
\hline N.R.577 & 8.6E-05 & 0 & 4.6E-05 & $2.9 \mathrm{E}-05$ & 0.67 & 0.025 & Betaproteobacteria (C) \\
\hline 167760 & $1.1 \mathrm{E}-03$ & $1.1 \mathrm{E}-05$ & $1.1 \mathrm{E}-04$ & $5.5 \mathrm{E}-04$ & 0.87 & 0.005 & Aeromonadaceae (F) \\
\hline \multicolumn{8}{|c|}{ SDM + Echinostome } \\
\hline N.R.O & 5.7E-05 & 1.7E-03 & 4.9E-03 & $2.9 \mathrm{E}-04$ & 0.90 & 0.015 & Flavobacteriaceae(F) \\
\hline \multicolumn{8}{|c|}{ SDM + SDM/Echinostome } \\
\hline N.R.776 & 0 & $1.5 \mathrm{E}-04$ & $1.1 \mathrm{E}-05$ & $1.4 \mathrm{E}-04$ & 0.76 & 0.010 & Emticicia \\
\hline N.R.1480 & $6.9 \mathrm{E}-05$ & $8.8 \mathrm{E}-04$ & 4.6E-05 & $7.9 E-04$ & 0.81 & 0.010 & Leadbetterella \\
\hline N.R.644 & $1.1 \mathrm{E}-05$ & $1.1 \mathrm{E}-03$ & $3.5 \mathrm{E}-04$ & $9.1 \mathrm{E}-04$ & 0.71 & 0.040 & Limnobacter \\
\hline 150430 & 0 & 5.7E-05 & 0 & $1.3 \mathrm{E}-04$ & 0.71 & 0.005 & Burkholderiales (O) \\
\hline 140758 & $3.4 \mathrm{E}-05$ & $5.5 \mathrm{E}-04$ & $6.3 \mathrm{E}-05$ & $6.2 \mathrm{E}-04$ & 0.74 & 0.020 & Pseudomonadaceae (F) \\
\hline N.R.342 & $3.4 \mathrm{E}-05$ & $3.9 \mathrm{E}-04$ & $7.4 \mathrm{E}-05$ & $1.4 \mathrm{E}-04$ & 0.81 & 0.045 & Pseudomonadaceae (F) \\
\hline N.R.813 & 4.0E-05 & $3.3 \mathrm{E}-03$ & $2.2 \mathrm{E}-04$ & $2.8 \mathrm{E}-03$ & 0.82 & 0.025 & Saprospiraceae (F) \\
\hline \multicolumn{8}{|c|}{ Echinostome + SDM/Echinostome } \\
\hline N.R.1346 & 1.7E-05 & 0 & $1.3 \mathrm{E}-04$ & $2.2 \mathrm{E}-04$ & 0.76 & 0.005 & Rikenellaceae (F) \\
\hline 539293 & 1.0E-02 & $6.0 \mathrm{E}-03$ & 4.6E-02 & 3.3E-02 & 0.86 & 0.010 & Cytophagaceae (F) \\
\hline N.R.214 & 0 & $5.8 \mathrm{E}-04$ & 3.0E-03 & $2.3 \mathrm{E}-03$ & 0.82 & 0.005 & Flavobacterium \\
\hline N.C.R.509135 & 0 & 0 & $3.2 \mathrm{E}-04$ & $6.3 \mathrm{E}-04$ & 0.71 & 0.010 & Ruminococcaceae (F) \\
\hline
\end{tabular}


Table 2 (Continued)

\begin{tabular}{|c|c|c|c|c|c|c|c|}
\hline OTUs & C & $\mathbf{A}$ & $\mathbf{P}$ & $\mathbf{P} / \mathbf{A}$ & Ass. & p-val & Genus \\
\hline \multicolumn{8}{|c|}{ Echinostome + SDM/Echinostome (continued) } \\
\hline N.R.854 & $1.2 \mathrm{E}-03$ & 8.9E-04 & 8.0E-03 & 8.1E-03 & 0.89 & 0.005 & Clostridiales (O) \\
\hline N.C.R.175211 & 0 & 0 & $3.4 \mathrm{E}-05$ & $3.4 \mathrm{E}-05$ & 0.63 & 0.010 & Comamonadaceae (F) \\
\hline N.R.266 & 4.0E-05 & 2.3E-05 & 8.5E-03 & $1.2 \mathrm{E}-02$ & 0.74 & 0.030 & Comamonadaceae (F) \\
\hline N.C.R.313149 & 0 & 1.7E-05 & 2.1E-04 & $1.7 \mathrm{E}-04$ & 0.85 & 0.005 & Oxalobacteraceae (F) \\
\hline 242252 & 1.1E-05 & 8.0E-05 & 2.5E-03 & $1.8 \mathrm{E}-03$ & 0.83 & 0.015 & Propionivibrio \\
\hline 738230 & 1.7E-05 & 5.7E-06 & 4.0E-05 & $1.4 \mathrm{E}-04$ & 0.73 & 0.020 & Shewanella \\
\hline N.R.247 & 2.3E-05 & 1.7E-05 & $3.5 \mathrm{E}-04$ & $1.0 \mathrm{E}-03$ & 0.73 & 0.025 & Luteolibacter \\
\hline N.R.417 & 3.0E-04 & 3.7E-04 & 1.3E-02 & 7.0E-03 & 0.93 & 0.005 & Luteolibacter \\
\hline N.R.1390 & 6.3E-05 & $3.6 \mathrm{E}-04$ & 3.7E-03 & $2.4 \mathrm{E}-03$ & 0.78 & 0.015 & Porphyromonadaceae (F) \\
\hline N.R.1473 & $1.4 \mathrm{E}-04$ & $2.5 \mathrm{E}-04$ & 4.7E-04 & $3.9 \mathrm{E}-03$ & 0.74 & 0.050 & Bacteroidales (O) \\
\hline \multicolumn{8}{|c|}{ Control + SDM + Echinostome } \\
\hline 239526 & $7.4 \mathrm{E}-04$ & 9.7E-05 & 3.4E-04 & $1.5 \mathrm{E}-04$ & 0.86 & 0.020 & Rhodobacter \\
\hline 4343658 & $7.1 \mathrm{E}-04$ & $1.2 \mathrm{E}-04$ & $9.1 \mathrm{E}-05$ & 5.7E-05 & 0.81 & 0.050 & Alphaproteobacteria (C) \\
\hline 672144 & $1.6 \mathrm{E}-04$ & 1.3E-04 & 7.4E-05 & $1.7 \mathrm{E}-05$ & 0.78 & 0.025 & Comamonadaceae (F) \\
\hline N.R.149 & $1.2 \mathrm{E}-04$ & 4.6E-05 & $5.1 \mathrm{E}-05$ & $1.1 \mathrm{E}-05$ & 0.75 & 0.025 & Propionibacterium \\
\hline \multicolumn{8}{|c|}{ Control + Echinostome + SDM/Echinostome } \\
\hline 816960 & 1.7E-04 & 1.1E-05 & 4.6E-05 & $1.6 \mathrm{E}-04$ & 0.74 & 0.045 & Comamonadaceae (F) \\
\hline N.R.1170 & 3.7E-04 & 4.6E-05 & $1.4 \mathrm{E}-04$ & $1.6 \mathrm{E}-04$ & 0.83 & 0.045 & Comamonadaceae (F) \\
\hline N.R.1345 & $2.9 \mathrm{E}-04$ & 1.7E-05 & $1.5 \mathrm{E}-04$ & $1.3 \mathrm{E}-04$ & 0.86 & 0.005 & Comamonadaceae (F) \\
\hline N.C.R.233611 & $1.4 \mathrm{E}-04$ & 2.9E-05 & $1.5 \mathrm{E}-04$ & 1.7E-04 & 0.83 & 0.020 & Betaproteobacteria (C) \\
\hline \multicolumn{8}{|c|}{ Control + SDM + SDM/Echinostome } \\
\hline 563957 & $3.2 \mathrm{E}-04$ & $1.4 \mathrm{E}-04$ & $2.9 \mathrm{E}-05$ & $1.1 \mathrm{E}-04$ & 0.84 & 0.015 & Rhizobiales (0) \\
\hline 2251859 & $5.3 E-04$ & $1.4 \mathrm{E}-03$ & $1.1 \mathrm{E}-05$ & $2.8 \mathrm{E}-04$ & 0.77 & 0.040 & Sphingomonadaceae (F) \\
\hline N.R.232 & $1.3 \mathrm{E}-03$ & 4.6E-04 & $1.1 \mathrm{E}-04$ & $2.1 \mathrm{E}-04$ & 0.91 & 0.035 & Sphingobacteriales (O) \\
\hline 258654 & $1.0 \mathrm{E}-03$ & $2.9 \mathrm{E}-03$ & 2.0E-04 & $1.5 \mathrm{E}-03$ & 0.95 & 0.035 & Comamonadaceae (F) \\
\hline 585221 & $2.2 \mathrm{E}-04$ & $1.5 \mathrm{E}-04$ & 4.6E-05 & $1.6 \mathrm{E}-04$ & 0.91 & 0.005 & Comamonadaceae (F) \\
\hline 324252 & $1.5 \mathrm{E}-03$ & $6.9 \mathrm{E}-04$ & $1.8 \mathrm{E}-04$ & 4.4E-04 & 0.94 & 0.020 & Rhodocyclaceae (F) \\
\hline 2194875 & $1.9 \mathrm{E}-03$ & 8.0E-04 & 1.3E-04 & $4.2 \mathrm{E}-04$ & 0.93 & 0.015 & Rhodocyclaceae (F) \\
\hline 279948 & $2.2 \mathrm{E}-04$ & $3.4 \mathrm{E}-04$ & 4.6E-05 & $1.9 \mathrm{E}-04$ & 0.87 & 0.010 & Pseudomonas \\
\hline 295031 & 2.6E-04 & $2.3 \mathrm{E}-04$ & 4.0E-05 & $1.4 \mathrm{E}-04$ & 0.89 & 0.020 & Pseudomonas \\
\hline \multicolumn{8}{|c|}{ SDM + Echinostome + SDM/Echinostome } \\
\hline 4362005 & $3.8 \mathrm{E}-03$ & $2.4 \mathrm{E}-02$ & 2.0E-02 & $1.4 \mathrm{E}-02$ & 0.97 & 0.005 & Emticicia \\
\hline N.R.983 & $2.2 \mathrm{E}-03$ & 2.8E-02 & 9.7E-03 & $2.8 \mathrm{E}-02$ & 0.97 & 0.005 & Flavobacterium \\
\hline N.R.892 & $1.6 \mathrm{E}-04$ & $1.2 \mathrm{E}-03$ & 6.7E-04 & $1.2 \mathrm{E}-03$ & 0.84 & 0.010 & Pedobacter \\
\hline 140767 & $1.2 \mathrm{E}-04$ & $4.8 \mathrm{E}-04$ & $5.8 \mathrm{E}-04$ & $5.4 \mathrm{E}-04$ & 0.91 & 0.005 & Exiguobacterium \\
\hline 578911 & 5.1E-05 & 2.7E-04 & 2.6E-04 & $1.4 \mathrm{E}-04$ & 0.75 & 0.050 & Exiguobacterium \\
\hline 695260 & 2.3E-05 & 3.9E-04 & $2.2 \mathrm{E}-04$ & $3.4 \mathrm{E}-04$ & 0.88 & 0.005 & Rhizobiaceae (F) \\
\hline
\end{tabular}


Table 2 (Continued)

\begin{tabular}{|c|c|c|c|c|c|c|c|}
\hline OTUs & C & $\mathbf{A}$ & $\mathbf{P}$ & $\mathbf{P} / \mathbf{A}$ & Ass. & & Genus \\
\hline \multicolumn{8}{|c|}{ SDM + Echinostome + SDM/Echinostome (continued) } \\
\hline N.C.R.224290 & 0 & 4.7E-04 & $2.9 \mathrm{E}-04$ & $3.9 \mathrm{E}-04$ & 0.82 & 0.005 & Rhodobacter \\
\hline 4405881 & 2.3E-04 & $7.4 \mathrm{E}-04$ & $5.8 \mathrm{E}-04$ & $1.2 \mathrm{E}-03$ & 0.86 & 0.050 & Limnobacter \\
\hline 570204 & $6.3 \mathrm{E}-05$ & $1.3 \mathrm{E}-03$ & $2.1 \mathrm{E}-04$ & $5.2 \mathrm{E}-04$ & 0.88 & 0.020 & Comamonadaceae (C) \\
\hline 582007 & 0 & $1.5 \mathrm{E}-04$ & $1.6 \mathrm{E}-04$ & $6.1 \mathrm{E}-04$ & 0.84 & 0.010 & Comamonadaceae (C) \\
\hline 1634030 & $2.9 \mathrm{E}-05$ & 3.0E-04 & $3.6 \mathrm{E}-04$ & 1.7E-04 & 0.86 & 0.010 & Comamonadaceae (C) \\
\hline N.C.R.30123 & 1.7E-05 & 3.3E-04 & $3.6 \mathrm{E}-04$ & $2.8 \mathrm{E}-04$ & 0.81 & 0.030 & Comamonadaceae (C) \\
\hline N.R.1297 & 1.7E-05 & $3.4 \mathrm{E}-04$ & $5.2 \mathrm{E}-04$ & $2.8 \mathrm{E}-04$ & 0.94 & 0.005 & Comamonadaceae (C) \\
\hline 605409 & 8.0E-05 & $5.3 \mathrm{E}-04$ & $6.8 \mathrm{E}-04$ & $3.6 \mathrm{E}-04$ & 0.91 & 0.015 & Burkholderiales (O) \\
\hline 574862 & $6.2 \mathrm{E}-04$ & $1.1 \mathrm{E}-03$ & $6.2 \mathrm{E}-03$ & 7.3E-03 & 0.91 & 0.015 & Methylotenera \\
\hline N.C.R.500944 & 4.0E-05 & 4.6E-04 & $2.1 \mathrm{E}-04$ & 4.1E-04 & 0.82 & 0.020 & Betaproteobacte \\
\hline N.R.117 & 8.6E-05 & $3.1 \mathrm{E}-04$ & $2.2 \mathrm{E}-04$ & 2.9E-04 & 0.83 & 0.045 & Betaproteobacteria (C) \\
\hline N.R.967 & $4.8 \mathrm{E}-03$ & $1.8 \mathrm{E}-02$ & 1.1E-02 & 2.3E-02 & 0.96 & 0.035 & Betaproteobacteria (C) \\
\hline 4312845 & $1.8 \mathrm{E}-04$ & $2.8 \mathrm{E}-03$ & $1.6 \mathrm{E}-03$ & $6.7 \mathrm{E}-04$ & 0.93 & 0.005 & Rheinheimera \\
\hline N.R.1499 & 2.9E-05 & 1.7E-04 & $1.1 \mathrm{E}-04$ & $1.5 \mathrm{E}-04$ & 0.81 & 0.040 & HTCC \\
\hline 559204 & $2.0 \mathrm{E}-04$ & $2.5 \mathrm{E}-03$ & $2.8 \mathrm{E}-03$ & $3.0 \mathrm{E}-03$ & 0.99 & 0.005 & Enterobacteriaceae (F) \\
\hline N.C.R.31981 & $6.3 \mathrm{E}-05$ & $1.5 \mathrm{E}-04$ & $3.1 \mathrm{E}-04$ & $3.0 \mathrm{E}-04$ & 0.93 & 0.005 & Enterobacteriaceae $(\mathrm{F})$ \\
\hline 321584 & $3.5 \mathrm{E}-04$ & 2.0E-03 & $3.3 \mathrm{E}-03$ & $2.4 \mathrm{E}-03$ & 0.98 & 0.005 & Acinetobacter \\
\hline N.R.433 & 0 & $2.6 \mathrm{E}-03$ & $1.5 \mathrm{E}-03$ & $6.2 \mathrm{E}-03$ & 0.88 & 0.005 & Sinobaceraceae (F) \\
\hline N.R.1227 & 4.6E-05 & 1.7E-02 & 2.0E-03 & $1.1 \mathrm{E}-02$ & 0.97 & 0.005 & Prosthecobacter \\
\hline 541887 & $3.8 \mathrm{E}-04$ & $6.0 \mathrm{E}-03$ & $1.1 \mathrm{E}-03$ & $3.9 \mathrm{E}-03$ & 0.84 & 0.015 & Verrucomicrobiaceae (F) \\
\hline N.R.1438 & 5.9E-04 & 1.0E-02 & $1.2 \mathrm{E}-02$ & $8.4 \mathrm{E}-03$ & 0.92 & 0.005 & Cyanobacteria (C) \\
\hline
\end{tabular}

treatments did not have a significant effect on overall host health.

To our knowledge, our study is the first to evaluate the effect of low environmentally relevant concentrations of an agricultural antimicrobial on the skin microbiota of amphibians [30]. SDM alone did not influence the richness/diversity of skin bacterial communities on northern leopard frogs but did alter beta diversity. At least among amphibian studies, previous antibiotic studies typically use higher concentrations (e.g., nine times higher than used in our study) or a cocktail spanning different pharmacodynamics with the intention to drastically interfere with microbial function [21]. Thus, at low concentrations, SDM may not eliminate members of the microbial community [77]; but, as we show, can facilitate certain bacteria and shift microbiota structure between the control and treatment groups [78]. These results are consistent with the taxonomic shift observed in previous studies on soil microbial communities where relative abundances of bacteria in the phyla Proteobacteria, Firmicutes, and Bacteroidetes increased following sulfonamide application [79, 80].
Collectively, these results suggest that considering low environmentally relevant concentrations of antibiotics is important as these concentrations can impose significant changes on host-associated communities of natural flora/fauna.

Echinostome exposure had no effect on skin microbial community richness; however, it resulted in an increase in bacterial community evenness and differentiation between individuals exposed to the parasite and controls. The influence of echinostome exposure on Shannon diversity indices corresponds with the observed increase in relative abundance of certain OTUs (i.e., Flavobacterium and Acinetobacter). This pattern has been observed in a salmonid-lice system, where infection by cutaneous parasites benefitted the propagation of opportunistic microbes in the skin [40]. However, this study is the first to demonstrate that a non-cutaneous amphibian parasite can induce changes to the amphibian skin microbiome. Interestingly, infection by the non-cutaneous parasite (echinostome) stimulated changes in the northern leopard frog skin microbiota composition in a similar degree to those observed when other ranids are infected with cutaneous parasites 
(i.e., $B d ;[6,81])$. Commonalities between the community disruption effect of $B d$ and echinostomes suggest that additional infection-related mechanisms, other than direct disturbance of the skin integrity, might influence the skin microbiota of amphibians. Given the increasing evidence that amphibians commonly experience co-infection with multiple types of pathogens [82], future studies should investigate how other cutaneous and non-cutaneous pathogens affect the skin microbiota of amphibians and whether these changes influence host susceptibility/resistance to infection by multiple pathogens.

Contrary to our prediction, the combination of echinostome and SDM exposure did not interact antagonistically on alpha diversity. We anticipated an antagonistic response because antimicrobials can deplete microbial richness and select for resistant bacteria [83], while infection with a parasite can result in colonization with opportunistic microbes [6]. The low levels of SDM used in our study did not reduce alpha diversity; thus, this is likely the reason why there was no antagonistic effect. Given that SDM has been recorded at concentrations of up to $36 \mu \mathrm{g}^{-1}$ in aquatic systems [39], antagonistic responses of wild amphibian microbiotas to parasite and antibiotic exposure remain a possibility. Echinostome exposure had a significant effect on weighted UniFrac distances; however, we found significant effects of these two treatments based on unweighted UniFrac and Bray-Curtis distances. This pattern suggests that the parasite and antimicrobial influenced the composition (e.g., presence/absence of OTUs) of the microbial community as opposed to the structure (e.g., abundance of OTUs; [84]). Yet, when tadpoles were exposed to the combination of echinostomes and SDM, we noted no differences in beta diversity between SDM-exposed, echinostome-exposed, and echinostome + SDM-exposed individuals. Thus, the effect of the parasite was similar to the effect of the antimicrobial on the skin microbiota of the tadpoles, indicating that parasite infection likely bestows stressrelated effects on the microbiota [85]. Our results demonstrate a complex response of the amphibian skin microbiota to a common parasite and contaminant. Given the diversity of anthropogenic and natural stressors facing wildlife populations and the recognition that these stressors commonly co-occur [86], more studies considering effects of simultaneous stressors on the microbiota in the laboratory and natural settings are necessary.

Exposure to SDM and echinostome certainly shifted the composition of the skin microbiota of tadpoles, with consistent increases in the relative abundances of OTUs identified to the genera Flavobacterium and Acinetobacter. While we cannot specifically address the mechanisms behind the shift observed, we can induce that SDM and echinostome might impose a degree of physiological stress. In human and animal models, physiological stress generated by environmental stimuli (e.g., pathogen or pollutant exposure) can bestow an indirect effect on the resident microbiota [87]. In amphibians and fish, cutaneous integrity and commensal community structure is promoted in part through the secretion of antimicrobial proteins (AMP's) by skin granular glands [88]. However, stressinduced increases in corticosteroids have been associated with a decrease in secreted AMP's [89], interrupting microbial regulatory mechanisms on the skin [90] that may regulate microbial communities in the tadpole [91]. Changes to physiology might explain why Flavobacterium and Acinetobacter increase their relative abundance over other members of the tadpole microbiota. Our methodology did not allow us to determine if Flavobacterium and Acinetobacter are pathogenic or beneficial. However, both of these genera have been associated with infectious disease in amphibians and the production of anti-pathogen metabolites [24, 92-94]. Therefore, future investigations might benefit from incorporating functional characterization to determine the impact of microbiota disturbance on host health.

Finally, SDM did not affect overall host health or susceptibility to echinostome infection. Our results are congruent with previous studies which have shown that infection rates of 50 or fewer echinostomes have no effect on amphibian survival and little to no effect on host traits, depending on the species $[19,28]$. Interestingly, though we did not see an effect of SDM on host health or echinostome susceptibility, amphibian skin microbial communities were altered. Notably, given the time frame of our study, it remains unclear whether the observed changes in the microbiota will affect the host long-term, suggesting it may be necessary to extend the period of observation in future studies [95]. These results suggest that the use of traditional host-health metrics in toxicological and disease research may not always sufficiently convey the overall effects of these potential stressors on the host. Importantly, shifts in microbiota beta diversity could be used as an early indicator of either chemical contamination or parasite exposure. Collectively, these findings underscore the importance of utilizing a holistic approach that characterizes both microbiome and host health.

Our results provide considerations for the study of hostassociated microbiotas in natural systems. Our study highlights the need to continue to evaluate the influence of natural and anthropogenic factors that alter host-associated microbial communities. We have shown that a parasite and contaminant may impose changes on the microbiota despite an absence of influence on host health. Given the link between the microbiome and disease resistance in amphibians, it is important to evaluate how common pollutants and amphibian parasites alter the host immune system and microbiomes (gut and skin; [30]). In addition, parasite-related changes to the microbiota suggest the need to further characterize how varying infection intensities, co-infections, natural bacterial reservoirs, and host life stages may alter the effects observed in the current study. Continuing to holistically characterize the response of hosts and their microbial symbionts to common natural and 
anthropogenic stressors will allow further understanding of the microbial ecology of host-associated microbiomes in our changing world.

Acknowledgments We thank the Purdue University Department of Forestry and Natural Resources Genetics Laboratory for allowing us to perform the microbiota laboratory work in their facility. We also thank the staff of the Cornell University Biotechnology Resource Center for their assistance in sequencing. Finally, we thank Nicholas Buss for collecting the leopard frog egg masses. All animals were handled in accordance with the Binghamton University IACUC protocol 757-16.

Funding Funding for this research was provided by NSF DEB 1655190 to JH, NSF PRFB 1708926 to OHG, and by Binghamton University's Sustainable Communities Transdisciplinary Areas of Excellence to VW.

\section{Compliance with Ethical Standards}

Conflict of Interest The authors declare that they have no conflicts of interest.

Ethical Approval All applicable international, national, and/or institutional guidelines for the care and use of animals were followed.

\section{References}

1. Costello EK, Stagaman K, Dethlefsen L, Bohannan BJM, Relman DA (2012) The application of ecological theory toward an understanding of the human microbiome. Science 336:1255-1262. https://doi.org/10.1126/science.1224203

2. Grice EA, Segre JA (2012) The human microbiome: our second genome. Annu Rev Genomics Hum Genet 13:151-170. https://doi. org/10.1146/annurev-genom-090711-163814

3. Kaplan JL, Shi HN, Walker WA (2011) The role of microbes in developmental immunologic programming. Pediatr Res 69:465472. https://doi.org/10.1203/PDR.0b013e318217638a

4. Turnbaugh PJ, Ley RE, Hamady M, Fraser-Liggett CM, Knight R, Gordon JI (2007) The human microbiome project. Nature 449:804810. https://doi.org/10.1038/nature06244

5. Cho I, Blaser MJ (2012) The human microbiome: at the Interface of health and disease. Nat Rev Genet 13:260-270. https://doi.org/10. 1038/nrg3182

6. Jani AJ, Briggs CJ (2014) The pathogen Batrachochytrium dendrobatidis disturbs the frog skin microbiome during a natural epidemic and experimental infection. Proc Natl Acad Sci U S A 111:E5049-E5058. https://doi.org/10.1073/pnas.1412752111

7. Soen Y (2014) Environmental disruption of host-microbe co-adaptation as a potential driving force in evolution. Front Genet 5:168. https://doi.org/10.3389/fgene.2014.00168

8. Stecher B, Robbiani R, Walker AW, Westendorf AM, Barthel M, Kremer M, Chaffron S, Macpherson AJ, Buer J, Parkhill J, Dougan G, von Mering C, Hardt W-D (2007) Salmonella enterica serovar typhimurium exploits inflammation to compete with the intestinal microbiota. PLoS Biol 5:2177-2189. https://doi.org/10.1371/ journal.pbio.0050244

9. Petersen C, Round JL (2014) Defining Dysbiosis and its influence on host immunity and disease. Cell Microbiol 16:1024-1033. https://oi.org/10.1111/cmi.12308
10. Berendsen RL, Pieterse CMJ, Bakker P (2012) The rhizosphere microbiome and plant health. Trends Plant Sci 17:478-486. https://doi.org/10.1016/j.tplants.2012.04.001

11. Harris RN, Brucker RM, Walke JB, Becker MH, Schwantes CR, Flaherty DC, Lam BA, Woodhams DC, Briggs CJ, Vredenburg VT, Minbiole KPC (2009) Skin microbes on frogs prevent morbidity and mortality caused by a lethal skin fungus. ISME J 3:818-824. https://doi.org/10.1038/ismej.2009.27

12. Stecher B, Hardt WD (2008) The role of microbiota in infectious disease. Trends Microbiol 16:107-114. https://doi.org/10.1016/j. tim.2007.12.008

13. Brown SP, Inglis RF, Taddei F (2009) Evolutionary ecology of microbial wars: within-host competition and (incidental) virulence. Evol Appl 2:32-39. https://doi.org/10.1111/j.1752-4571.2008. 00059.x

14. Dheilly NM, Poulin R, Thomas F (2015) Biological warfare: microorganisms as drivers of host-parasite interactions. Infect Genet Evol 34:251-259. https://doi.org/10.1016/j.meegid.2015.05.027

15. Boutin S, Bernatchez L, Audet C, Derome N (2013) Network analysis highlights complex interactions between pathogen, host and commensal microbiota. PLoS One 8:e84772. https://doi.org/10. 1371/journal.pone. 0084772

16. Kelly C, Salinas I (2017) Under pressure: interactions between commensal microbiota and the teleost immune system. Front Immunol 8:559. https://doi.org/10.3389/fimmu.2017.00559

17. Dietrich JP, Van Gaest AL, Strickland SA, Arkoosh MR (2014) The impact of temperature stress and pesticide exposure on mortality and disease susceptibility of endangered Pacific Salmon. Chemosphere 108:353-359. https://doi.org/10.1016/j. chemosphere.2014.01.079

18. Doublet V, Labarussias M, de Miranda JR, Moritz RFA, Paxton RJ (2015) Bees under stress: sublethal doses of a neonicotinoid pesticide and pathogens interact to elevate honey bee mortality across the life cycle. Environ Microbiol 17:969-983. https://doi.org/10. 1111/1462-2920.12426

19. Hua J, Wuerthner VP, Jones DK, Mattes B, Cothran RD, Relyea RA, Hoverman JT (2017) Evolved pesticide tolerance influences susceptibility to parasites in amphibians. Evol Appl 10:802-812. https://doi.org/10.1111/eva.12500

20. De Liguoro M, Poltronieri C, Capolongo F, Montesissa C (2007) Use of Sulfadimethoxine in intensive calf farming: evaluation of transfer to stable manure and soil. Chemosphere 68:671-676. https://doi.org/10.1016/j.chemosphere.2007.02.009

21. Becker MH, Harris RN (2010) Cutaneous bacteria of the redback salamander prevent morbidity associated with a lethal disease. PLoS One 5:e10957. https://doi.org/10.1371/journal.pone.0010957

22. Colombo BM, Scalvenzi T, Benlamara S, Pollet N (2015) Microbiota and mucosal immunity in amphibians. Front Immunol 6. https://doi.org/10.3389/fimmu.2015.00111

23. Daszak P, Berger L, Cunningham AA, Hyatt AD, Green DE, Speare $R$ (1999) Emerging infectious diseases and amphibian population declines. Emerg Infect Dis 5:735-748. https://doi.org/10.3201/ eid0506.990601

24. Becker MH, Walke JB, Murrill L, Woodhams DC, Reinert LK, Rollins-Smith LA, Burzynski EA, Umile TP, Minbiole KPC, Belden LK (2015) Phylogenetic distribution of symbiotic bacteria from Panamanian amphibians that inhibit growth of the lethal fungal pathogen Batrachochytrium dendrobatidis. Mol Ecol 24:16281641. https://doi.org/10.1111/mec.13135

25. Johnson PTJ, McKenzie VJ (2009) Effects of environmental change on helminth infections in amphibians: exploring the emergence of Ribeiroia and Echinostoma infections in North America. In: Toledo R, Fried B (eds) The biology of Echinostomes. Springer, New York, pp 249-280

26. Martin TR, Conn DB (1990) The pathogenicity, localization, and cyst structure of Echinostomatid Metacercariae (Trematoda) 
infecting the kidneys of the frogs Rana clamitans and Rana pipiens. J Parasitol 76:414 419. https://doi.org/10.2307/3282677

27. Hoverman JT, Mihaljevic JR, Richgels KLD, Kerby JL, Johnson PTJ (2012) Widespread co-occurrence of virulent pathogens within California amphibian communities. Ecohealth 9:288-292. https:// doi.org/10.1007/s10393-012-0778-2

28. Wuerthner VP, Hua J, Hoverman JT (2017) The benefits of coinfection: trematodes alter disease outcomes associated with virus infection. J Anim Ecol 86:921-931. https://doi.org/10.1111/13652656.12665

29. Reid KM, Patel S, Robinson AJ, Bu LJ, Jarungsriapisit J, Moore LJ, Salinas I (2017) Salmonid alphavirus infection causes skin Dysbiosis in Atlantic Salmon (Salmo salar L.) Post-smolts. PLoS One 12. https://doi.org/10.1371/journal.pone.0172856

30. Jimenez RR, Sommer S (2017) The amphibian microbiome: natural range of variation, pathogenic dysbiosis, and role in conservation. Biodivers Conserv 26:763-786. https://doi.org/10.1007/s10531016-1272-x

31. Costa S, Lopes I, Proenca DN, Ribeiro R, Morais PV (2016) Diversity of cutaneous microbiome of Pelophylax perezi populations inhabiting different environments. Sci Total Environ 572: 995-1004. https://doi.org/10.1016/j.scitotenv.2016.07.230

32. Koprivnikar J, Forbes MR, Baker RL (2007) Contaminant effects on host-parasite interactions: atrazine, frogs, and trematodes. Environ Toxicol Chem 26:2166-2170. https://doi.org/10.1897/07220.1

33. Pochini KM, Hoverman JT (2017) Immediate and lag effects of pesticide exposure on parasite resistance in larval amphibians. Parasitology 144:817-822. https://doi.org/10.1017/ s0031182016002560

34. Buss N, Hua J (2018) Parasite susceptibility in an amphibian host is modified by salinization and predators. Environ Pollut 236:754 763. https://doi.org/10.1016/j.envpol.2018.01.060

35. Rohr JR, Raffel TR, Sessions SK, Hudson PJ (2008) Understanding the net effects of pesticides on amphibian trematode infections. Ecol Appl 18:1743-1753. https://doi.org/10.1890/07-1429.1

36. Crisol-Martinez E, Moreno-Moyano LT, Wilkinson N, Prasai T, Brown PH, Moore RJ, Stanley D (2016) A low dose of an organophosphate insecticide causes dysbiosis and sex-dependent responses in the intestinal microbiota of the Japanese quail (Coturnix japonica). Peerj 4:e2002. https://doi.org/10.7717/peerj. 2002

37. Daszak P, Cunningham AA, Hyatt AD (2000) Emerging infectious diseases of wildlife - threats to biodiversity and human health. Science 287:443-449. https://doi.org/10.1126/science.287.5452. 443

38. Keesing F, Belden LK, Daszak P, Dobson A, Harvell CD, Holt RD, Hudson P, Jolles A, Jones KE, Mitchell CE, Myers SS, Bogich T, Ostfeld RS (2010) Impacts of biodiversity on the emergence and transmission of infectious diseases. Nature 468:647-652. https:// doi.org/10.1038/nature09575

39. Dietze JE, Scribner EA, Meyer MT, Kolpin DW (2005) Occurrence of antibiotics in water from 13 Fish hatcheries, 2001-2003. Int J Environ Anal Chem 85:1141-1152. https://doi.org/10.1080/ 03067310500273682

40. Llewellyn MS, Leadbeater S, Garcia C, Sylvain FE, Custodio M, Ang KP, Powell F, Carvalho GR, Creer S, Elliot J, Derome N (2017) Parasitism perturbs the mucosal microbiome of Atlantic Salmon. Sci Rep 7. https://doi.org/10.1038/srep43465

41. Woodhams DC, Geiger CC, Reinert LK, Rollins-Smith LA, Lam B, Harris RN, Briggs CJ, Vredenburg VT, Voyles J (2012) Treatment of amphibians infected with Chytrid fungus: learning from failed trials with itraconazole, antimicrobial peptides, bacteria, and heat therapy. Dis Aquat Org 98:11-25. https://doi.org/10.3354/ dao02429
42. Appelgate J (1983) Clinical-pharmacology of sulfonamides. Mod Vet Pract 64:667-669

43. Giguere S, Prescott JF, Dowling PM (2013) Antimicrobial therapy in veterinary medicine 5 th edn. Wiley-Blackwell, Hoboken

44. Bourne DWA, Bialer M, Dittert LW, Hayashi M, Rudawsky G, Koritz GD, Bevill RF (1981) Disposition of sulfadimethoxine in cattle-inclusion of protein-binding factors in a pharmacokinetic model. J Pharm Sci 70:1068-1072. https://doi.org/10. 1002/jps.2600700926

45. Hamscher G, Priess B, Nau H (2006) A survey of the occurrence of various sulfonamides and tetracyclines in water and sediment samples originating from aquaculture systems in Northern Germany in summer 2005. Arch Leb 57:97-101

46. Kreuzig R, Holtge S, Brunotte J, Berenzen N, Wogram J, Schulz R (2005) Test-plot studies on runoff of sulfonamides from manured soils after sprinkler irrigation. Environ Toxicol Chem 24:777-781. https://doi.org/10.1897/04-019r.1

47. Kuchta SL, Cessna AJ, Elliott JA, Peru KM, Headley JV (2009) Transport of Lincomycin to surface and ground water from manureamended cropland. J Environ Qual 38:1719-1727. https://doi.org/ $10.2134 /$ jeq2008.0365

48. Kumar A, Schweizer HP (2005) Bacterial resistance to antibiotics: active efflux and reduced uptake. Adv Drug Deliv Rev 57:14861513. https://doi.org/10.1016/j.addr.2005.04.004

49. Sarmah AK, Meyer MT, Boxall ABA (2006) A global perspective on the use, sales, exposure pathways, occurrence, fate and effects of veterinary antibiotics (VAs) in the environment. Chemosphere 65:725-759. https://doi.org/10.1016/j. chemosphere.2006.03.026

50. Huffman JE, Fried B (2012) The biology of Echinoparyphium (Trematoda, Echinostomatidae). Acta Parasitol 57:199-210. https://doi.org/10.2478/s11686-012-0042-5

51. Kanev I, Sterner M, Radev V, Fried B (2000) An overview of the biology of echinostomes. In: Fried B, Graczyk TK (eds) Echinostomes as experimental models for biological research. Springer, Dordrecht, pp 1-29

52. Schell SC (1985) Handbook of the trematodes of North America north of Mexico. University Press of Idaho, Moscow

53. Smyth JD, Halton DW (1983) The physiology of trematodes 2nd edn. Cambridge University Press, New York

54. Anderson RM, May RM (1978) Regulation and stability of hostparasite population interactions: 1. Regulatory Processes. J Anim Ecol 47:219-247. https://doi.org/10.2307/3933

55. Gervasi SS, Stephens PR, Hua J, Searle CL, Xie GY, Urbina J, Olson DH, Bancroft BA, Weis V, Hammond JI, Relyea RA, Blaustein AR (2017) Linking ecology and epidemiology to understand predictors of multi-host responses to an emerging pathogen, the amphibian Chytrid fungus. PLoS One 12: e0167882. https://doi.org/10.1371/journal.pone.0167882

56. Walke JB, Becker MH, Loftus SC, House LL, Teotonio TL, Minbiole KPC, Belden LK (2015) Community structure and function of amphibian skin microbes: an experiment with bullfrogs exposed to a Chytrid fungus. PLoS One 10. https://doi.org/10. 1371/journal.pone. 0139848

57. Culp CE, Falkinham III JO, Belden LK (2007) Identification of the natural bacterial microflora on the skin of eastern newts, bullfrog tadpoles and Redback salamanders. Herpetologica 63: 66-71. https://doi.org/10.1655/0018-0831(2007)63[66: iotnbm]2.0.co;2

58. McKenzie VJ, Bowers RM, Fierer N, Knight R, Lauber CL (2012) Co-habiting amphibian species harbor unique skin bacterial communities in wild populations. ISME J 6:588-596. https://doi.org/10. 1038/ismej.2011.129

59. LaFonte BE, Johnson PTJ (2013) Experimental infection dynamics: using immunosuppression and In Vivo parasite tracking to 
understand host resistance in an amphibian-trematode system. $\mathrm{J}$ Exp Biol 216:3700-3708. https://doi.org/10.1242/jeb.088104

60. Holland MP, Skelly DK, Kashgarian M, Bolden SR, Harrison LM, Cappello M (2007) Echinostome infection in Green frogs (Rana clamitans) is stage and age dependent. J Zool 271:455-462. https://doi.org/10.1111/j.1469-7998.2006.00229.x

61. Hernández-Gómez O, Hoverman JT, Williams RN (2017) Cutaneous microbial community variation across populations of eastern hellbenders (Cryptobranchus alleganiensis alleganiensis). Front Microbiol 8. https://doi.org/10.3389/fmicb.2017.01379

62. Hernández-Gómez O, Kimble SJA, Briggler JT, Williams RN (2017) Characterization of the cutaneous bacterial communities of two Giant salamander subspecies. Microb Ecol 73:445-454. https://doi.org/10.1007/s00248-016-0859-9

63. Fierer N, Hamady M, Lauber CL, Knight R (2008) The influence of sex, handedness, and washing on the diversity of hand surface Bacteria. Proc Natl Acad Sci U S A 105:17994-17999. https:// doi.org/10.1073/pnas.0807920105

64. Bolger AM, Lohse M, Usadel B (2014) Trimmomatic: a flexible trimmer for Illumina sequence data. Bioinformatics 30:2114-2120. https://doi.org/10.1093/bioinformatics/btu170

65. Masella AP, Bartram AK, Truszkowski JM, Brown DG, Neufeld JD (2012) PANDAseq: PAired-eND assembler for Illumina sequences. BMC Bioinformatics 13:31. https://doi.org/10.1186/ 1471-2105-13-31

66. Caporaso JG, Kuczynski J, Stombaugh J, Bittinger K, Bushman FD, Costello EK, Fierer N, Pena AG, Goodrich JK, Gordon JI, Huttley GA, Kelley ST, Knights D, Koenig JE, Ley RE, Lozupone CA, McDonald D, Muegge BD, Pirrung M, Reeder J, Sevinsky JR, Tumbaugh PJ, Walters WA, Widmann J, Yatsunenko T, Zaneveld J, Knight R (2010) QIIME allows analysis of high-throughput community sequencing data. Nat Methods 7:335-336. https://doi.org/10. 1038/nmeth.f.303

67. Rideout JR, He Y, Navas-Molina JA, Walters WA, Ursell LK, Gibbons SM, Chase J, McDonald D, Gonzalez A, RobbinsPianka A, Clemente JC, Gilbert JA, Huse SM, Zhou H-W, Knight R, Caporaso JG (2014) Subsampled open-reference clustering creates consistent, comprehensive OTU definitions and scales to billions of sequences. Peerj 2. https://doi.org/10. $7717 /$ peerj. 545

68. DeSantis TZ, Hugenholtz P, Larsen N, Rojas M, Brodie EL, Keller K, Huber T, Dalevi D, Hu P, Andersen GL (2006) Greengenes, a chimera-checked 16S rRNA gene database and workbench compatible with ARB. Appl Environ Microbiol 72:5069-5072. https:// doi.org/10.1128/aem.03006-05

69. Cole JR, Wang Q, Fish JA, Chai B, McGarrell DM, Sun Y, Brown CT, Porras-Alfaro A, Kuske CR, Tiedje JM (2014) Ribosomal database project: data and tools for high throughput rRNA analysis. Nucleic Acids Res 42:D633-D642

70. Bokulich NA, Subramanian S, Faith JJ, Gevers D, Gordon JI, Knight R, Mills DA, Caporaso JG (2013) Quality-filtering vastly improves diversity estimates from Illumina amplicon sequencing. Nat Methods 10:57-U11. https://doi.org/10.1038/ nmeth. 2276

71. Oksanen J, Blanchet FG, Friendly M, Kindt R, Legendre P, McGlinn D, Minchin PR, O'Hara RB, Simpson GL, Solymos P, Stevens MHH, Szoecs E, Wagner H (2017) Vegan: community ecology package

72. Kembel SW, Cowan PD, Helmus MR, Cornwell WK, Morlon H, Ackerly DD, Blomberg SP, Webb CO (2010) Picante: R tools for integrating phylogenies and ecology. Bioinformatics 26:1463-1464

73. Chen J (2012) GUniFrac: generalized UniFrac distances

74. Venebles WN, Ripley BD (2002) Modern applied statistics with S. Springer, New York
75. De Caceres M, Legendre P (2009) Associations between species and groups of sites: indices and statistical inference. Ecology 90: 3566-3574

76. Gosner KL (1960) A simplified table for staging anuran embryos and larvae with notes on identification. Herpetologica 16:183-190

77. Gao PP, Mao DQ, Luo Y, Wang LM, Xu BJ, Xu L (2012) Occurrence of sulfonamide and tetracycline-resistant bacteria and resistance genes in aquaculture environment. Water Res 46:2355-2364. https://doi.org/10.1016/j.watres.2012.02.004

78. Bernier SP, Surette MG (2013) Concentration-dependent activity of antibiotics in natural environments. Front Microbiol 4. https://doi. org/10.3389/fmicb.2013.00020

79. Ding GC, Radl V, Schloter-Hai B, Jechalke S, Heuer H, Smalla K, Schloter M (2014) Dynamics of soil bacterial communities in response to repeated application of manure containing sulfadiazine. PLoS One 9. https://doi.org/10.1371/ journal.pone.0092958

80. Islas-Espinoza M, Reid BJ, Wexler M, Bond PL (2012) Soil bacterial consortia and previous exposure enhance the biodegradation of sulfonamides from pig manure. Microb Ecol 64:140-151. https:// doi.org/10.1007/s00248-012-0010-5

81. Jani AJ, Knapp RA, Briggs CJ (2017) Epidemic and endemic pathogen dynamics correspond to distinct host population microbiomes at a landscape scale. Proc R Soc B 284:20170944. https://doi.org/ 10.1098/rspb.2017.0944

82. Stutz WE, Blaustein AR, Briggs CJ, Hoverman JT, Rohr JR, Johnson PTJ (2017) Using multi-response models to investigate pathogen coinfections across scales: insights from emerging diseases of amphibians. Methods Ecol Evol 9:1109-1120. https:// doi.org/10.1111/2041-210X.12938

83. Carlson JM, Hyde ER, Petrosino JF, Manage ABW, Primm TP (2015) The host effects of Gambusia affinis with an antibioticdisrupted microbiome. Comp Biochem Physiol C 178:163-168. https://doi.org/10.1016/j.cbpc.2015.10.004

84. Lozupone C, Knight R (2005) UniFrac: a new phylogenetic method for comparing microbial communities. Appl Environ Microbiol 71: 8228-8235. https://doi.org/10.1128/aem.71.12.8228-8235.2005

85. Belkaid Y, Segre JA (2014) Dialogue between skin microbiota and immunity. Science 346:954-959. https://doi.org/10.1126/science. 1260144

86. Kiesecker JM (2002) Synergism between trematode infection and pesticide exposure: a link to amphibian limb deformities in nature? Proc Natl Acad Sci U S A 99:9900-9904. https://doi.org/10.1073/ pnas. 152098899

87. Galley JD, Bailey MT (2014) Impact of stressor exposure on the interplay between commensal microbiota and host inflammation. Gut Microbes 5:390-396. https://doi.org/10.4161/gmic.28683

88. Simmaco M, Mignogna G, Barra D (1998) Antimicrobial peptides from amphibian skin: what do they tell us? Biopolymers 47:435450. https://doi.org/10.1002/(sici)1097-0282(1998)47:6<435::aidbip3>3.0.co;2-8

89. Simmaco M, Boman A, Mangoni ML, Mignogna G, Miele R, Barra D, Boman HG (1997) Effect of glucocorticoids on the synthesis of antimicrobial peptides in amphibian skin. FEBS Lett 416: 273-275. https://doi.org/10.1016/s0014-5793(97)01216-7

90. Gomez D, Sunyer JO, Salinas I (2013) The mucosal immune system of Fish: the evolution of tolerating commensals while fighting pathogens. Fish Shellfish Immunol 35:1729-1739. https://doi.org/ 10.1016/j.fsi.2013.09.032

91. Woodhams DC, Brandt H, Baumgartner S, Kielgast J, Kuepfer E (2014) Interacting symbionts and immunity in the amphibian skin mucosome predict disease risk and probiotic effectiveness. PLoS One 9:e96375. https://doi.org/10.1371/journal. pone. 0104590 
92. Olson ME, Gard S, Brown M, Hampton R, Morck DW (1992) Flavobacterium-indologenes infection in leopard frogs. J Am Vet Med Assoc 201:1766-1770

93. Lauer A, Simon MA, Banning JL, Andre E, Duncan K, Harris RN (2007) Common cutaneous bacteria from the eastern redbacked salamander can inhibit pathogenic fungi. Copeia 630 640. https://doi.org/10.1643/0045-8511(2007)2007[630: ccbfte]2.0.co;2
94. Mauel MJ, Miller DL, Frazier KS, Hines ME (2002) Bacterial pathogens isolated from cultured bullfrogs (Rana castesbeiana). J Vet Diagn Investig 14:431-433. https://doi.org/10.1177/ 104063870201400515

95. Knutie SA, Wilkinson CL, Kohl KD, Rohr JR (2017) Early-life disruption of amphibian microbiota decreases later-life resistance to parasites. Nat Commun 8:86. https://doi.org/10.1038/s41467017-00119-0 